\title{
ANTIMICROBIAL RESISTANCE AND SEROTYPING OF STREPTOCOCCUS PNEUMONIAE ISOLATED FROM PEDIATRIC PATIENTS IN BELO HORIZONTE, MG, BRAZIL
}

\author{
Ana Paula Gomes de Oliveira Magalhães; Artur da Silveira Pinto* \\ Departamento de Microbiologia, Instituto de Ciências Biológicas, Universidade Federal de Minas Gerais, \\ Campus da Pampulha, Belo Horizonte, MG, Brasil.
}

Submitted: August 07, 2002; Returned to Authors: January 13, 2003; Approved: July 08, 2003

\section{SHORT COMMUNICATION}

\begin{abstract}
Thirty one Streptococcus pneumoniae invasive strains were isolated from a pediatric population in Belo Horizonte from June, 1999 to May, 2001. Penicillin, trimethoprim-sulfamethoxazole, tetracycline and choramphenicol resistance rates for the isolates were 41.9, 58.1, 25.8 and 3.2\%, respectively. Intermediate penicillin resistant (MICs between 0.1 and $1.0 \mu \mathrm{g} / \mathrm{ml}$ ) and resistant (MICs $>2.0 \mu \mathrm{g} / \mathrm{ml}$ ) isolates occured at rates of 38.7 and $3.2 \%$, respectively. Resistance to erythromycin, ofloxacin, rifampin or vancomicyn was not detected. Ten S. pneumoniae serotypes (14, 5, 10 A, 6B, 15B, 18C, 6 A, 18 A, 19 A and 19 F) were identified. Serotype 14 (12 out of 31) was predominant among the isolates. Penicillin and trimethoprim-sulfamethoxazole resistance was more common in 14 and $6 \mathrm{~B}$ serotypes.
\end{abstract}

Key words: Streptococcus pneumoniae, antimicrobial resistance, serotyping.

Pneumonia and meningitis due to invasive strains of Streptococcus pneumoniae are important cause of children morbity and mortality worldwide. Children under 2 years of age are the most susceptible to pneumococcal infections. The treatment of such infections relies mostly on penicillin therapy. In recent years, the emergence and rapid spread of strains resistant to penicillin and other antimicrobial agents have been of considerable concern (6). Immunization using polyvalent pneumococcal conjugate vaccines shown to be immunogenic to very young children, have been proposed. These vaccines appear to be effective in prevention of infections both with invasive and antimicrobial resistant $S$. pneumoniae serotypes. However, S. pneumoniae serotypes distribution is variable worldwide and the correct formulation of these vaccines has been determined only for United States and Europe $(7,8)$. At present, only few data about the antimicrobial susceptibility and serotype occurence of pneumococci in the pediatric population of Belo Horizonte are available. Thus, knowledge about the $S$. pneumoniae population from children in this region may help treatment planning and preventive strategies.

A total of 31 clinical isolates of S. pneumoniae was recovered from June, 2000 to May, 2001 from children (0 to 73 mouths old), at the Centro Geral de Pediatria (CGP), a pediatric Hospital in Belo Horizonte, Minas Gerais, Brazil. Isolation was performed by plating the collected material on Agar Chocolate and incubating under $\mathrm{CO}_{2}$ atmosphere, at $37^{\circ} \mathrm{C}$. Sixteen isolates were recovered from meningitis (liquor and blood) and 15 from pneumonia diagnosed patients (blood and plueral fluid). Isolates were identified as S. pneumoniae their colonial morphology, Gram staining optochin (ethyl hydrocuprein hydrochloride) susceptibility and bile solubility tests. The isolates were serotyped by the Quellung reaction method with the Pneumotest kit (Statens Seruminstitut, Copenhagen, Denmark), at the Instituto Adolfo Lutz, São Paulo, SP, Brazil.

*Corresponding author. Mailing address: Departamento de Microbiologia, Instituto de Ciências Biológicas, Universidade Federal de Minas Gerais. Avenida Antônio Carlos, 6627, Pampulha. 31270-901, Belo Horizonte, MG, Brasil. Tel.: (+5531) 3499-2749. Fax: (+5531) 3499-2730. E-mail: dasilvei@mono.icb.ufmg.br. 
Susceptibility tests to penicillin (oxacillin), erythromycin, tetracycline, choramphenicol, sulfamethoxazole-trimethoprim, ofloxacin, rifampin and vancomycin were done by the KirbyBauer disk diffusion method. Results were interpreted according to guidelines of the National Committee for Clinical Laboratory Standards (NCCLS). Penicillin G minimal inhibitory concentrations (MICs) were determined by the E-Test ${ }^{\circledR}$ method (AB Biodisk, Solona, Sweden). Susceptibility to penicillin G was categorized as susceptible if MIC was $<0.06 \mu \mathrm{g} / \mathrm{mL}$, intermediate if MIC was between 0.1 and $1.0 \mu \mathrm{g} / \mathrm{mL}$, and resistant if MIC was $\geq 2.0 \mu \mathrm{g} / \mathrm{mL}$. The susceptible strain of $S$. penumoniae ATCC 49616 was used as control.

The antimicrobial susceptibility and the serotypes identified in the present survey are presented in Table 1. Among the isolates, $41.95 \%$ ( 13 out of 31 ) presented altered susceptibility to penicillin. Twelve (12 out of 31,38.7\%) of them presented intermediate resistance and 1 ( 1 out of $31,3.2 \%$ ) full resistance to penicillin (Fig. 1). Resistance to this b-lactamic antibiotic was always associated with resistance to trimethoprimsulfamethoxazole. In addition, the only are multidrug-resistant isolate was also associated to these two drugs, and also to tetracycline. Resistance to tetracycline and chloramphenicol was found to be $25.8 \%$ ( 7 out of 31 ) and $3.2 \%$ (1 out of 31), respectively. Resistance to erythromycin, ofloxacin, rifampin and vancomycin, was not detected.

Althougth preliminary, these results lead to important observations. First, the resistance to penicillin (41.95\%) among

Table 1. Antimicrobial resistance patterns and serotype distribution of invasive $S$. pneumoniae strains isolated from a pediatric population in Belo Horizonte, MG, Brazil.

\begin{tabular}{lccccccccccc}
\hline $\begin{array}{c}\text { Antimicrobial } \\
\text { resistance } \\
\text { pattern }\end{array}$ & 14 & 5 & $10 \mathrm{~A}$ & $6 \mathrm{~B}$ & $15 \mathrm{~B}$ & $18 \mathrm{C}$ & $6 \mathrm{~A}$ & $18 \mathrm{~A}$ & $19 \mathrm{~A}$ & $19 \mathrm{~F}$ & Total \\
\hline $\mathrm{P}^{a}$ & - & - & - & - & - & - & - & - & - & - & - \\
$\mathrm{T}$ & 2 & 1 & - & - & 1 & 1 & 2 & - & - & - & 7 \\
$\mathrm{TS}$ & - & 3 & 2 & - & - & - & - & - & - & - & 5 \\
$\mathrm{C}$ & - & - & 1 & - & - & - & - & - & - & - & 1 \\
$\mathrm{E}$ & - & - & - & - & - & - & - & - & - & - & - \\
$\mathrm{O}$ & - & - & - & - & - & - & - & - & - & - & - \\
$\mathrm{R}$ & - & - & - & - & - & - & - & - & - & - & - \\
$\mathrm{V}$ & - & - & - & - & - & - & - & - & - & - & - \\
$\mathrm{P}, \mathrm{TS}$ & 9 & - & - & 3 & - & - & - & - & - & - & 12 \\
$\mathrm{P}, \mathrm{TS}, \mathrm{T}$ & 1 & - & - & - & - & - & - & - & - & - & 1 \\
& & & & & & & & & & & \\
Susceptible & - & - & - & - & 1 & 1 & - & 1 & 1 & 1 & 5 \\
& & & & & & & & & & \\
Total & 12 & 4 & 3 & 3 & 2 & 2 & 2 & 1 & 1 & 1 & 31 \\
\hline
\end{tabular}

${ }^{a}$ P, penicillin; $\mathrm{T}$, tetracyclin; TS, trimethoprim-sulfamethoxazole; $\mathrm{C}$, chloramphenicol; E, erythromicin; O, ofloxacin; R, rifampin; V, vancomycin. the isolates from these pediatric population was practically two fold higher than detected in Brazilan children (21.1\%) in the 1993-1996 period (10). Our data suggest that, like in other countries, also in Brazil there is also a tendency for an increase in the rate of resistance to penicillin among S. pneumoniae isolated. In addition, the level of resistance to penicillin detected in the present survey seems to be much lower than in industrialized countries, such as France, Spain, and United States (54.0 to $65.0 \%)(3,16)$, South Korea (79.7\%), Taiwan (70.0\%), Japan $(65.3 \%)$ and Singapore $(63.3 \%)(9,14,15)$. In this survey, isolates exhibited predominantly intermediate resistance to penicillin with MICs between 0.1 and $1.0 \mu \mathrm{g} / \mathrm{mL}$. This resistance profile apparently has been maintained unchanged during the recent years in Brazil (10). On the other hand, this profile is radically different from that found in Asian countries like South Korea, Taiwan, and Indonesia, where alarming MICs of $8.0 \mu \mathrm{g} / \mathrm{mL}$ or higher were detected (15). In our study, most of the penicillin-resistant isolates were also trimethoprimsulfamethoxazole resistant. High prevalence of resistance to trimethoprim-sulfamethoxazole is seen in Latin America, Asia, Europe and United States and may reflect the worldwide use of this drug association $(13,14)$. A similar fact may be occuring with tetracycline since it is the second most commonly prescribed drug after penicillin worldwide (11). The level of chloramphenicol resistance was low in in the present study probably because nowadays this drug is not frequently administred to pediatric patients, mainly due to the poor bactericidal activity of chloramphenicol against $S$. penumoniae (4). Resistance to erythromycin, ofloxacin, rifampin or vancomycin was not detected in this survey. However, resistance to these drugs has been welldocumented in pneumococcus isolated from children in other countries, like France, Spain and South Africa $(1,5,11)$.

There were 10 serotypes among 31 invasive strains of $S$. pneumoniae isolated in the present survey. Determination of the main serotypes that cause pneumococcal infection in each region of the world is of major importance in public health because of polyvalent conjugate vaccine formulations. For example, the $7-\mathrm{V}$ vaccine formulation $(4,6 \mathrm{~B}, 9 \mathrm{~V}, 14,18 \mathrm{C}$, 19Fand 23F serotypes) contains the most common serotypes in United States, Canada and Australia, six of the most common in Europe, five of the most common in Latin America and four of the most commmon in Africa and Asia (7). Our results indicate that only four of the seven most common serotypes of $S$. pneumoniae isolates from the pediatric population of Belo Horizonte are present in the $7-\mathrm{V}$ vaccine formulation. Worse, only five of the serotypes are present in both $9-\mathrm{V}$ vaccine (7-V plus 1,5 serotypes) or $11-\mathrm{V}$ vaccine (9$\mathrm{V}$ plus 3, 7F serotypes) formulations. All penicillin resistant isolates belonged to the 14 and $6 \mathrm{~B}$ serotypes. These serotypes are frequently associated with penicillin resistance in Brazil, Latin America (2) and Asian countries (9) and confirm 
observations that, in each region of the world, at least $80 \%$ of the antibiotic resistant $S$. pneumoniae serotypes appear to be represented in the 7-V vaccine formulation (7).

A more detailed study over a wider area and for a longer period of time on the pneumococcus antimicrobial resistance and serotypes distribution among the pediatric population of Belo Horizonte is needed. Such study may help a controlled use of antimicrobial agents and the development of an effective polyvalent conjugate vaccine.

\section{ACKNOWLEDGEMENTS}

We are most gratefull to the Centro Geral de Pediatria (CGP), Belo Horizonte, MG, Brazil, for use of their facilities and to the Division of Bacteriology of Instituto Adolfo Lutz. SP, Brazil for performing the isolates serology.

\section{RESUMO}

\section{Resistência antimicrobiana e sorotipagem de Streptococcus pneumoniae isolado de pacientes pediátricos em Belo Horizonte, MG}

Trinta e três linhagens invasivas do $S$. pneumoniae foram isoladas a partir de pacientes pediátricos em Belo Horizonte, MG, Brasil, de junho de 1999 a maio de 2001. As taxas de resistência à penicilina, ao trimetoprim-sultametoxazol, tetraciclina e cloranfenicol foram respectivamente, 41, 9; 58,1 e $3,2 \%$. A resistência intermediária à penicilina (MICs entre $0,1 \mathrm{e}$ $1,0 \mu \mathrm{g} / \mathrm{ml}$ ) e resistência total (MICs $>2.0 \mu \mathrm{g} / \mathrm{ml}$ ) ocorreram, respectivamente, nas porcentagens de 38,7 e 3,2\%. Não foi detectada resistência à eritromicina, ofloxacin, rifampina e vancomicina. Foram identificados 9 sorotipos do S. pneumoniae $(14,5,10,6 \mathrm{~B}, 15 \mathrm{~B}, 18 \mathrm{C}, 6 \mathrm{~A}, 18 \mathrm{19} \mathrm{Ae} 19 \mathrm{~F})$ entre os isolados. O sorotipo 14 (12 de 31) foi predominate entre os isolados. A resistência à penicilina e ao trimetoprim-sulfametoxazol estava sempre associada aos sorotipos 14 e 6B.

Palavras-chave: Streptococcus pneumoniae, resistência antimicrobiana, sorotipagem.

\section{REFERENCES}

1. Baquero, F. Trends in antibiotic resistance of respiratory pathogens: an analysis and commentary on a collaborative surveillance study. $J$. Antimicrob. Chemother., 38(Suppl.A):117-132, 1996.

2. Brandileone, M.C.C.; Vieira, V.S.D.; Casagrande, S.T.; Zanella, R.C.; Guerra, M.L.L.S.; Brandão, A.P.; Melles, C.E.A. Pignatari, A.C.C.;
Di Fabio, J.L.; Austrian, R. Characterictics of isolates of Streptococcus pneumoniae from medle aged and elderly adults in Brazil: capsular serotypes and antimicrobial sensivity with invasive infection. Braz. J. Infec. Dis., 2:90-96, 1998.

3. Diekema, D.J.; Brueggeman, A.B.; Doern, G.V. Antimicrobial-drug use and changes in resistance in Streptococcus pneumoniae. Emerg. Infect. Dis., 6:552-556, 2000.

4. Friendland, I.R.; McCracken, G.H. Failure of chloramphenicol therapy in penicillin resistant pneumococcal meningitis. Lancet, 339:405408, 1992.

5. Geslin, P.; Buu-Hoi, A.; Frémaux, A.; Acar, J.F. Antimicrobial resistance in Streptococcus pneumoniae: an epidemiological survey in France, 1970-1990. Clin. Infec. Dis., 15:95-98, 1992.

6. Greenwood, B. The epidemiology of pneumococcal infection in children in the developing world. Phil. Trans. R. Lond., B354:777$785,1999$.

7. Hausdroff, W.P.; Bryant, J.; Paradiso, P.R.; Siber, G.R. Which pneumococcal serogroups cause the most invasive disease: implications fpr conjugate vaccine formulation and use, Part I. Clin. Infect. Dis., 30:100-121, 2000.

8. Hausdroff, W.P.; Bryant, J.; Kloek, C.; Paradiso, P.R.; Silber, G.R. The contribution of specific pneumococcal serogroups of different disease manifestations: implication for conjugate vaccine formulation and use, Part II. Clin. Infect. Dis., 30:122-140.

9. Ip, M.J.; Lyon, D.J.; Young, R.W.H.; Chang, C.; Cheng, A.F.B. Evidence of clonal dissemination of multidrug-resistant Streptococcus pneumoniae in Hong Kong. J. Clin. Microbiol., 37:2837-2839, 1999.

10. Kertesz, D.A.; Di Fabio, J.L.; Brandileone, M.C.C.; Castañeda, E.; Echániz-Aviles, G.; Heitman, I.; Homma, A.; Hortal, M.; Lovgren, R.; Ruvinsky, R.O.; Talbot, J.A.; Weekes, J.; Spika, J.S.; PAHO Pneumococcal Surveillance Study Group. Invasive Streptococcus pneumoniae in Latin America children: results of the Pan American Health Organization Surveillance Study. Clin. Infect. Dis., 26:13551361, 1998.

11. Padayachee, T.; Klugman, K.P. Molecular basis of rifampin resistance in Streptococcus pneumoniae. Antimicrob. Agent. Chemother., 43:2361-2365, 1999.

12. Pradier, C.; Dunais, B.; Carsenti-Etesse, H.; Dellamonica, P. Pneumococcal resistance patterns in Europe. Eur. J. Clin. Microbiol. Infect. Dis., 16:644-647, 1997.

13. Sossegolo, F.F.; Levin, A.S.S.; Levy, C.E.; Asensi, M.; Facklam, P.R.; Teixeira, L.M. Distribution of serotypes and antimicrobial resistance of Streptococcus pneumoniae strains isolated in Brazil from 1988 to 1992. J. Clin. Microbiol., 32:906-911, 1994.

14. Soh, S.W.L.; Poh, C.L.R.; Lin, R.V.T.P. Serotype distribution and antimicrobial resistance of Streptococcus pneumoniae isolated from pediatric patients in Singapore. Antimicrob. Agents Chemother, 44:2193-2196, 2000.

15. Song, J.H.; Lee, N.Y.; Ichyama, S.; Yoshida, R.; Hirakata, Y.; Fu, W.; Chongthaleong, N.; Aswapokee, N.; Chiu, C.H.; Lalitha, M.K.; Thomas, K.; Perera, J.; Yee, T.T.; Jamal, F.; Warsa, U.C.; Vinh, B.X.; Jakobs, M.R.; Appelbaum, C.H.; Pai, C.H. ANSORP Study Group. Spreed of drug-resistant Streptococcus pneumoniae in Asian Countries: Asian Network for Surveillance of Resistant Pathogen (ANSORP) study. Clin. Infect. Dis., 28:1206-1211, 2000.

16. Thornsberry, C.; Sahm, D.F. Resistance in respiratory tract pathogens: an international study, 1997-1998. J. Chemother, 12(Suppl.4):1620,2000 . 